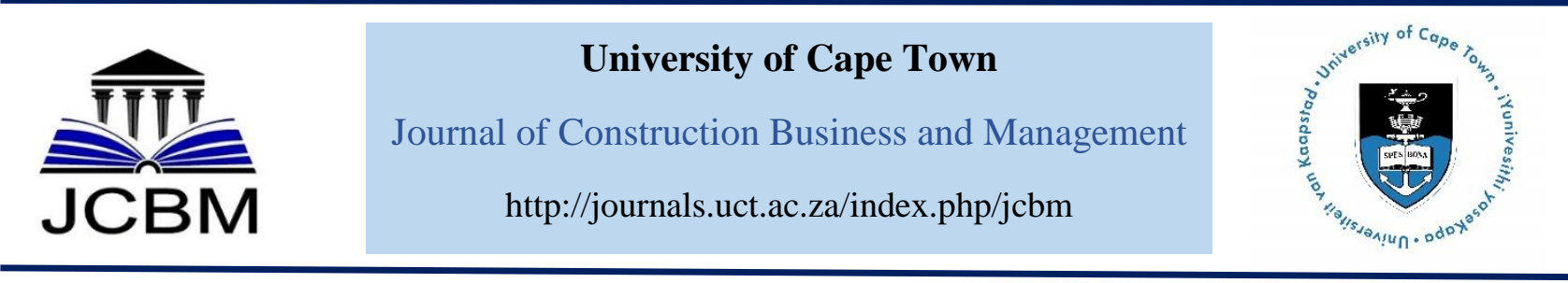

\title{
Determinants of Building Construction Costs in South Africa
}

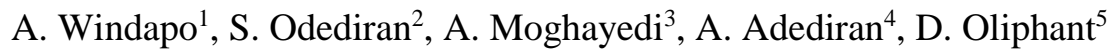 \\ Department of Construction Economics and Management, University of Cape Town, South Africa
}

\begin{abstract}
Completing project within cost is the target of most clients on any construction project. However, the achievement of this desire is just an imagination in the construction industry, because procurement and execution environments for projects are hostile and unpredictable. This study examines the determinants of building construction costs in South Africa and whether changes in the cost of certain resource factors such as construction equipment, labour and materials can be related to changes in building construction costs. The study employs a longitudinal cross-sectional quantitative research design approach and makes use of literature review and historical data obtained from institutional and governmental databases to identify the determinants. The data collected were analysed using time series analysis to confirm the trends in the cost of the resource factors and its alignment to the changes in building construction cost. After that, it makes use of an appropriate predictive modelling tool or causal analysis in establishing the determinants of construction cost. The results show that the price indices of construction equipment (EI), labour (LI) and materials (MI) have a gentler slope when compared with the Building Cost Index (BCI). It also emerged that later levels of the BCI are significantly and positively related to EI. The findings infer that the key determinant of increase in building construction costs in South Africa is equipment costs. Contractors and public or private sector clients in South Africa must utilize construction equipment optimally on projects, and these pieces of equipment should not be left idle on project sites or plant yards. Appropriate provisions should be made of equipment utilization policies which allow the joint ownership of equipment by contractors to mitigate the problems of cost increases. There are widely unexamined assumptions as to what resource factors are responsible for the growth in building construction costs in South Africa. Also is the similar high risk and uncertainty affecting the South African construction industry as a result of these fluctuations. The results of the study extend the knowledge of the resource factors responsible for building construction costs increases.
\end{abstract}

Keywords: Construction Equipment; Cost Data; Labour; Materials; South Africa.

\section{Introduction}

It is the desire of every client to achieve value for money on any construction project. This desire is often not met on most projects because of the unforeseen events and unpredictable factors influencing costs of projects at the planning and development stages. This study, therefore, examines factors that determine the cost of a construction project in South Africa. It also investigates whether the change in the cost of construction resources influences the trends in building costs. The outcome of this study informs contractors and public and private clients of the

\footnotetext{
${ }^{1}$ Corresponding Author. Tel: +27 216502049 .

E-mail address: abimbola.windapo@uct.ac.za

${ }^{2}$ E-mail address: ODDSUN001@myuct.ac.za

${ }^{3}$ E-mail address: MGHALI001@myuct.ac.za

${ }^{4}$ E-mail address: ADDABD001@ myuct.ac.za

${ }^{5}$ E-mail address: david.oliphant@uct.ac.za
}

likely level of increases in the cost of construction work, to predict future changes in the costs of construction projects. Hence, the paper presents in Section 1 an introduction, outline, and rationale of the study to readers. Section 2 describes a critical review of the literature on the drivers of construction cost. Chapter 3 discusses the method employed in collecting the data reported in the paper, while Section 4 outlines the findings emanating from the data analyzed and the results were related to the existing knowledge on drivers of construction costs. Section 5 presents the conclusions drawn from the results and highlights future research. 


\section{Identification and Review of Construction Cost Drivers}

Construction costs are the portion of hard costs usually associated with the construction contract, including the cost of materials, the labour and equipment costs necessary to put those elements in place. Overhead costs, which include both job site management and the contractors' standard cost of doing business are added to this.

Theoretical underpinning and constructs of the notable drivers of cost of construction work proposed in this research are aligned to the findings of previous studies by Odediran and Windapo (2014); American Institute of Architects (2013); Olatunji (2010); Skitmore et al. (2006);
Lowe et al. (2006); Sawhney et al. (2004), Ng et al. (2000); Akintoye et al. (1998); Fitzgerald and Akintoye (1995); Chau (1990); Eastman (1986); and Snyman (n.d). Based on literature review (see Tables 1 and 2), the drivers of construction costs are classified into-Resource factors (labour, material and plant); Project factors (competition intensity, profit margin, overhead cost, space available for construction, management skills provided, type of structure/design and construction methods used); Macroeconomic factors (demand and supply of construction work, finance or loan cost, inflation, transportation costs, energy costs, exchange rates and fuel price); construction work items (excavation, concrete work, formwork, reinforcement work, mechanical, electrical and plumbing installation etc.); and stakeholder requirements (professional fees and transaction costs).

Table 1: Resources Factors Based on Previous Studies

\begin{tabular}{|c|c|c|c|c|c|c|}
\hline \multirow[b]{2}{*}{ Resource Factors } & \multicolumn{5}{|c|}{ Relevant studies } & \multirow[b]{2}{*}{ No. Cited } \\
\hline & $\begin{array}{c}\text { Odediran \& } \\
\text { Windapo (2014) }\end{array}$ & $\begin{array}{c}\text { Skitmore et al. } \\
(2006)\end{array}$ & $\begin{array}{c}\text { Sawhney et al. } \\
(2004)\end{array}$ & $\begin{array}{c}\text { Eastham } \\
(1986)\end{array}$ & $\begin{array}{c}\text { Snyman } \\
\text { (n.d.) }\end{array}$ & \\
\hline Labour & $\checkmark$ & $\checkmark$ & $\checkmark$ & $\checkmark$ & $\checkmark$ & 5 \\
\hline Materials & $\checkmark$ & $\checkmark$ & $\checkmark$ & $\checkmark$ & & 4 \\
\hline Equipment/Plant & $\checkmark$ & $\checkmark$ & $\checkmark$ & $\checkmark$ & & 4 \\
\hline Sub-contractors & & & & $\checkmark$ & & 1 \\
\hline
\end{tabular}

Table 2: Project Factors Based on Previous Studies

\begin{tabular}{|c|c|c|c|c|c|c|c|}
\hline \multirow[b]{2}{*}{ Project Factors } & \multicolumn{6}{|c|}{ Relevant studies } & \multirow[b]{2}{*}{ No. Cited } \\
\hline & $\begin{array}{l}\text { Skitmore et } \\
\text { al. (2006) }\end{array}$ & $\begin{array}{l}\text { Sawhey et } \\
\text { al. (2004) }\end{array}$ & $\begin{array}{l}\text { Akintoye } \\
(2000)\end{array}$ & $\begin{array}{c}\text { Fitzgerald \& } \\
\text { Akintoye (1995) }\end{array}$ & $\begin{array}{c}\text { Eastham } \\
(1986)\end{array}$ & $\begin{array}{l}\text { Snyman } \\
\text { (n.d.) }\end{array}$ & \\
\hline Contracting practices & & $\checkmark$ & $\checkmark$ & & & & 2 \\
\hline Location & & & $\checkmark$ & & $\checkmark$ & & 2 \\
\hline Size of project & & & $\checkmark$ & & $\checkmark$ & & 2 \\
\hline Contract/project duration & & & $\checkmark$ & & $\checkmark$ & & 2 \\
\hline Tender period & & & $\checkmark$ & & $\checkmark$ & & 2 \\
\hline Quality of market information & & & $\checkmark$ & $\checkmark$ & & & 2 \\
\hline Bargaining Power of Unions & & & $\checkmark$ & $\checkmark$ & & & 2 \\
\hline Variations in materials & & $\checkmark$ & & & & & 1 \\
\hline Labour Productivity & & $\checkmark$ & & & & & 1 \\
\hline Equipment Usage & & $\checkmark$ & & & & & 1 \\
\hline Weather & & $\checkmark$ & & & & & 1 \\
\hline Soil conditions & & $\checkmark$ & & & & & 1 \\
\hline Quality standards expected & & $\checkmark$ & & & & & 1 \\
\hline Anticipated use & & $\checkmark$ & & & & & 1 \\
\hline Overhead cost & $\checkmark$ & & & & & & 1 \\
\hline Degree of competition & & & & & $\sqrt{ }$ & & 1 \\
\hline Method of construction & & & $\checkmark$ & & & & 1 \\
\hline Site constraints & & & $\checkmark$ & & & & 1 \\
\hline
\end{tabular}

The focus of this study will be of the contribution of resource factors to the cost of construction. Resource elements are the inputs used in the production process to produce an output - the final building or infrastructure product in development. According to Odediran and Windapo (2014); Skitmore et al. (2006); Sawhney et al. (2004); Eastham (1986); and Snyman (n.d), resource factors contributing to the cost of construction work in no particular order, are cost of construction equipment, labour, building materials and specialist sub-contractors. Building materials and materials will be used interchangeably in this paper.

\section{Research Methodology}


There are significant numbers of earlier studies either on cost forecasting or prediction in South Africa (Bowen, 1993; Snyman, 1989a; Snyman, 1989b; Bowen and Edwards, 1985; and Bowen, 1980). Historical cost data are mostly used for the purpose of predicting the future levels of construction costs as they provide trends in prices and reliable information than macroeconomic variables (Smith, 1995; Tysoe, 1981). This study examines resource factors - construction equipment, labour and building materials that are established in the literature. The study determines the relationship between the cost of these resource factors and construction costs and adopts a longitudinal cross-sectional survey research design in data collection.

A desk-top study that employs data collection methods involving data mining in achieving the research aim. The determinants of construction costs were established using historical information obtained from institutional and government databases (Stats SA, Bureau of Economic Research (BER)/Medium-Term Forecasting Associates (MFA) archives. The data/indices obtained were after that analyzed using descriptive tools to confirm the trends in the construction cost and after that, a predictive modelling tool or causal analysis to establish the determinants of building construction costs. Ashuri and $\mathrm{Lu}$ (2010) noted that the causal methods assume that the independent explanatory variables determine the variables to be predicted in the form of regression models. Ruddock (2008) acknowledged that regression and correlation are usually considered together in expressing a relationship between two variables. Simple or linear regression finds straight-line hypothesized relationships only, and mathematically represents this as equation (1):

\section{Where}

$$
y=a+b x
$$

$b=$ slope of the line of best fit (estimate/regression line) $x=$ values of the independent variable (that is resource factors in this study)

$y=$ values of the (hypothesized) dependent variable (that is BCI in this study)

$a=y$-intercept/constant

The Building Cost Index (BCI), which is a measure of the trends in the estimate of the cost required to complete a construction project, were used in the study as a measure of the growth in building construction cost. While the indexes of the resource factors - labour, material, and equipment, were used as a measure of the cost of the resource factors. The Labour Cost Index (LI) is a measure of the trends in the all-in-rate (payroll taxes and profits) of the skilled workers obtained from Department of Trade and Industry (Dti) records. The Building Material Price Index (MI) is a measure of the trend in changes in the prices of volatile construction materials. The indicator of building materials price trends used in this study is obtained from the published Building Materials Production Price Index available in the Stats SA archive. Also, the Plant Cost Index (EI) is used to measure the change in plant costs on a quarterly basis, is made up of construction equipment/plant hire rental (Stats SA, 2010).

According to Dysert (2008), regression modelling is a mathematical representation of cost relationships that provide a logical and predictable correlation between the physical or functional characteristics of a project (plant and process system) and its resultant cost. The process of regression modelling, therefore, lends itself towards the course of finding the significance between independent variables that have direct effects on a dependent variable, a contextual environment, which is typified by the construction process. Advantages of regression modelling for estimating purposes is the provision of efficiency regarding developing estimates in a shorter period. Linking quantitative inputs to algorithms to provide quantitative outputs, often allows two estimators to come to the same conclusion regarding cost, and it is flexible as it allows a range of independent input variables that have been derived from historical data (Black, 1984).

\section{Findings and Discussion}

Historical data collected from BER/MFA data and analyzed is presented and discussed in the following subsections.

\subsection{Trends in Historical Cost Data for Construction Costs and Resource Factors}

The study sought to know descriptively, the trends in the historical cost data for construction costs and the resource factors (construction equipment, labour, and building materials) in South Africa. The results of this inquiry are presented in Figures 1 and Table 3.

Table 3. Distribution of Building Cost, Labour, Material and Equipment Indices by Year (2010-2015)

\begin{tabular}{ccccc}
\hline Date & $\begin{array}{c}\text { Building } \\
\text { Cost Index (BCI) }\end{array}$ & $\begin{array}{c}\text { Normalized } \\
\text { Labour Index (LI) }\end{array}$ & $\begin{array}{c}\text { Normalized } \\
\text { Material Index (MI) }\end{array}$ & $\begin{array}{c}\text { Normalized } \\
\text { Equipment Index (EI) }\end{array}$ \\
\hline 2010Q1 & 145,7 & 174,5 & 216,5 & 188,3 \\
2010Q2 & 144,8 & 176,4 & 218,3 & 187,9 \\
2010Q3 & 142,0 & 177,8 & 218,9 & 186,7 \\
2010Q4 & 142,4 & 178,6 & 219,9 & 186,7 \\
2011Q1 & 140,8 & 181,2 & 223,3 & 186,0 \\
2011Q2 & 149,2 & 184,5 & 225,5 & 187,9 \\
$2011 Q 3$ & 147,8 & 187,4 & 228,3 & 189,2 \\
2011Q4 & 156,7 & 189,4 & 230,5 & 187,9 \\
2012Q1 & 153,3 & 191,8 & 233,1 & 185,9
\end{tabular}




\begin{tabular}{lllll} 
2012Q2 & 156,1 & 193,2 & 234,5 & 186,5 \\
2012Q3 & 161,4 & 194,1 & 235,5 & 187,4 \\
2012Q4 & 164,9 & 194,3 & 236,7 & 188,2 \\
2013Q1 & 171,0 & 197,3 & 239,5 & 189,8 \\
2013Q2 & 165,7 & 198,7 & 240,8 & 191,5 \\
2013Q3 & 173,3 & 200,3 & 242,9 & 194,9 \\
$2013 Q 4$ & 171,8 & 201,1 & 244,9 & 196,8 \\
$2014 Q 1$ & 179,2 & 203,3 & 247,1 & 198,7 \\
$2014 Q 2$ & 186,6 & 205,3 & 249,0 & 200,3 \\
$2014 Q 3$ & 191,2 & 206,8 & 249,9 & 200,8 \\
$2014 Q 4$ & 194,3 & 207,0 & 250,7 & 200,6 \\
2015Q1 & 198,2 & 207,7 & 250,5 & 202,2 \\
2015Q2 & 186,3 & 210,4 & 250,5 & 202,8 \\
$2015 Q 3$ & 196,2 & 212,0 & 250,9 & 203,6 \\
$2015 Q 4$ & 197,0 & 212,4 & 247,3 & 208,2 \\
\hline
\end{tabular}

Source: BER/MFA Data (2016)

Table 1 and Figure 1 compares the trends in Building Cost Index (BCI), Construction Equipment Index (EI), Labour Index (LI) and Material Index (MI). The result shows that the indices of equipment, labour, material have a gentler slope when compared with BCI. MI has a wider differential when compared to BCI. While the EI and LI have smaller differentials when compared to BCI, the growth rate of MI and LI are proportional except for the growth rate of EI which is not uniform over the years. There was an overlap in the growth rate of LI and EI in the year 2011 and 2012, meaning that the indices are to some extent unrelated. Moreover, the BCI, LI, and EI grew proportionally showing that they have the same growth rates.

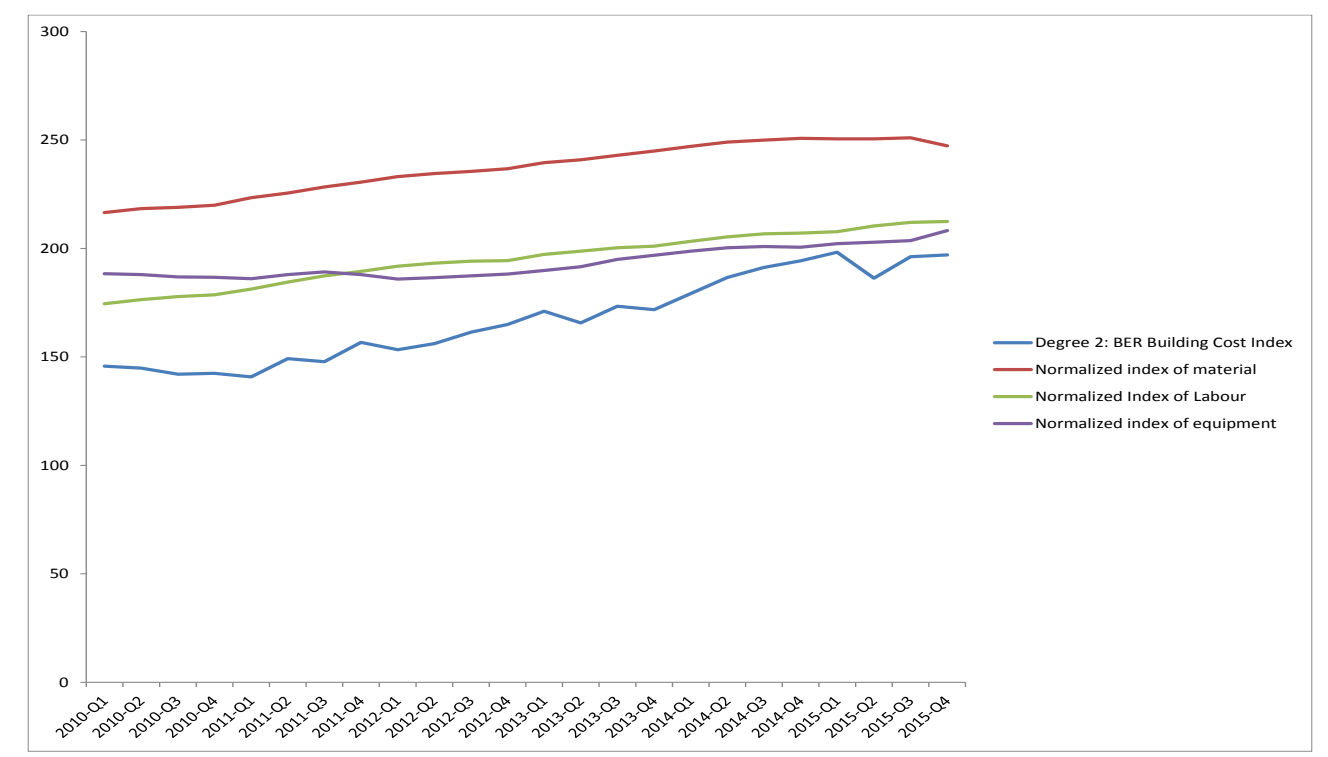

Figure 1: Comparing the Trends in Material, Labour, Equipment Indices and the BCI

\subsection{Multiple Regression between BCI, LI, MI and EI}

Further investigation was undertaken to find out whether there is any significant relationship between BCI (dependent variable) and LI, MI and EI (independent variables) using multiple regression analysis. Table 4 shows the results of the multiple regression analysis at 95\% confidence level between BCI, LI, MI and EI4.

Table 4 demonstrates that:

- The correlation between Building Cost Index (dependent variable) and Labour Index, Materials Index and Equipment Index (independent variable) is very high
(0.961556313) means $96 \%$ correlation - the combined changes in labour, materials, and equipment indices explains $96 \%$ of the changes in $\mathrm{BCI}$;

- Significance Value of Error is minuscule (2.56297E-

14) meaning that the error is not significant; and

- At $95 \%$ confidence level the $P$ value of the intercept is $1.85276 \mathrm{E}-07<0.05$, Labour Cost is $0.855670171>0.05$, Materials Cost is $0.08363076>0.05$ and Equipment Cost is $0.000101165<0.05$. The $\mathrm{P}$ values of the intercepts mean that the constant values of the intercept and Equipment cost are significant, but Labour cost and Materials Cost are not significant. 
- The relationship between BCI and the resource factors can be modeled as BCI $=-298,06+1,25 *$ EI.

Table 4. Multiple Regression between Building Cost Index, Labour Index, Material Index and Equipment Index (95\%)

\begin{tabular}{|c|c|c|c|c|c|}
\hline \multicolumn{6}{|c|}{ Regression Statistics } \\
\hline Multiple R & 0,98 & & & & \\
\hline R Square & 0,96 & & & & \\
\hline Adjusted R Square & 0,96 & & & & \\
\hline Standard Error & 4,17 & & & & \\
\hline Observations & 24 & & & & \\
\hline ANOVA & $d f$ & $S S$ & $M S$ & $\boldsymbol{F}$ & Significance $F$ \\
\hline Regression & 3 & 8689,86 & 2896,62 & 166,75 & $2,56297 \mathrm{E}-14$ \\
\hline Residual & 20 & 347,43 & 17,37 & & \\
\hline Total & 23 & 9037,29 & & & \\
\hline
\end{tabular}

\begin{tabular}{|c|c|c|c|c|c|c|c|c|}
\hline & Coefficients & $\begin{array}{c}\text { Standard } \\
\text { Error }\end{array}$ & t-Stat & P-value & $\begin{array}{c}\text { Lower } \\
95 \%\end{array}$ & $\begin{array}{c}\text { Upper } \\
95 \% \\
\end{array}$ & $\begin{array}{l}\text { Lower } \\
95.0 \%\end{array}$ & $\begin{array}{l}\text { Upper } \\
95.0 \%\end{array}$ \\
\hline Intercept & $-298,06$ & 38,40 & $-7,76$ & $1,85276 \mathrm{E}-07$ & $-378,17$ & $-217,96$ & $-378,17$ & $-217,96$ \\
\hline Labour & 0,10 & 0,52 & 0,18 & 0,855670171 & $-0,99$ & 1,18 & $-0,99$ & 1,18 \\
\hline Material & 0,87 & 0,48 & 1,82 & 0,083630760 & $-0,13$ & 1,86 & $-0,13$ & 1,86 \\
\hline Equipment & 1,25 & 0,26 & 4,83 & 0,000101165 & 0,71 & 1,78 & 0,71 & 1,78 \\
\hline
\end{tabular}

Based on these findings, it can be inferred that a unit increase in the price of equipment will lead to $25 \%$ increase in the cost of building construction. However, there was no significant relationship between building construction cost and the cost of materials and labour.

\section{Conclusions and Further Research}

The primary objective of any pricing regime should be to ensure that there is an efficient allocation of resources and an understanding of the indicators and drivers that will aid decision making, in managing cost related to the construction sector. This study examines the determinants of building construction costs in South Africa and whether changes in the cost of certain resource factors such as construction equipment, labour and materials can be related to changes in building construction costs. Overall, the research observed that although there is a gradual increase in construction cost, this is not increasing proportionally with inflation and that there is a significant positive relationship between construction costs and equipment costs when historical cost data are analyzed. It also emerged that a unit increase in the price of construction equipment will yield $25 \%$ increase in building construction cost. Based on these findings, it can the study concludes that equipment use is a major determinant of building construction costs in South Africa and that increases in equipment costs will yield proportionally significant increases in construction costs.

Based on these findings, the study recommends that contractors and public or private sector clients in South Africa must utilize construction equipment optimally on projects, and these pieces of equipment should not be left idle on project sites or plant yards. Appropriate provisions and policies should be made to allow the joint ownership of equipment by contractors to mitigate the problems of cost increases. The study also proposes that further research is undertaken using actual construction projects in validating the results obtained in this study.

\section{Acknowledgement}

This paper is a product of a wider study into the Drivers of Construction Costs funded by the Construction Industry Development Board/DPW in South Africa. The authors are grateful for the contributions from both agencies.

\section{References}

American Institute of Architecture. (2013). Construction Costs. Retrieved from American Institute of Architecture.:

http://www.aia.org/aiaucmp/groups/aia/documents/pdf/ai ab097618.pdf

Akintoye, S.A., Bowen, P. and Hardcastle, C. (1998). Macro-economic leading indicators of construction contract prices. Construction Management and Economics, 16, 159-175

Ashuri, B., \& Lu, J. (2010). 'Time Series Analysis of ENR Construction Cost Index' ASCE Journal of Construction Engineering and Management, 136(11), 1227-1237

Black, J. H. (1984). Application of parametric estimating to cost engineering. Association for the Advancement of Cost Engineering.

Bowen, P A (1980). An investigation into the feasibility of producing an econometric cost model for framed structures. Unpublished MSc (Construction Management) 
Thesis, Department of Building, Faculty of Engineering, Heriot-Watt University, Edinburgh. September.

Bowen, P A and Edwards, P J (1985). Cost modelling and price forecasting: practice and theory in perspective. Construction Management and Economics, 3, 199-215.

Bowen, P A (1993) A communication-based examination of price modelling and price forecasting in the design phase of the traditional building procurement process in South Africa. Unpublished Ph.D. Thesis, Department of Quantity Surveying, University of Port Elizabeth.

Bureau of Economic Research (BER) (2016). Building and Construction - First Quarter, BER, Stellenbosch

Chau, K.W. (1990). On the estimation of the price trend and output growth rate of the Hong Kong construction industry. Journal of Real Estate and Construction, 1, 4659

Department of Trade and Industry (dti) (2011). Data. Retrieved March 01, 2012, from dti.gov.za: http://www.dti.gov.za/econdb/cssrap/

Dysert, L. R. (2008). An Introduction to Parametric Estimating. Association for the Advancement of Cost Engineering.

Eastham, R.A. (1986). Contractors' perceptions of factors influencing tender prices for construction works. M.Sc. thesis. Department of Surveying, University of Salford.

Fitzgerald, E., and Akintoye, A. (1995). The accuracy and optimal linear correlation of UK construction tender price index forecasts. Construction Management and Economics, 13(6), 493-500.

Lowe, D. J., Emsley, M. W., \& Harding, A. (2006). Predicting Construction Cost Using Multiple Regression Techniques, ASCE Journal of Construction Engineering and Management, 132(7), 750-758.

MFA (Medium-Term Forecasting Associates) (2016). Report on Building Costs: Second Quarter 2016. Stellenbosch, South Africa.

Ng, S. T., Cheung, S. O., Skitmore, R. M., Lam, K. C., \& Wong, L. Y. (2000). Prediction of tender price index directional changes, Construction Management and Economics, 18(1), 843-852.
Odediran, S.J. and Windapo, A.O. (2014). Systematic review of factors influencing the cost performance of building projects In Laryea, S., and Ibem, E. (Eds). In: Proceedings of 8 th Construction Industry Development Board (cidb) Postgraduate Conference, 10-11 February, University of the Witwatersrand, Johannesburg, South Africa, pp. 501-520.

Olatunji, O.A. (2010). The impact of oil price regimes on construction cost in Nigeria. Construction Management and Economics, 28, 747-759

Ruddock, L., (2008) Approaches to Economic Modelling and Analysis, In Knight A and Ruddock L (eds.) Advanced Research Methods in Built Environment, Wiley-Blackwell: The United Kingdom, pp.51-62.

Sawhney, A., Walsh, K.D. and Brown IV, A. (2004). International comparison of cost for the construction sector: towards a conceptual model. Civil Engineering and Environmental Systems, 21(3), 151-167

Skitmore, M., Runeson, G. and Chang, X. (2006). Construction price formation: Full-cost pricing or neoclassical microeconomic theory? Construction Management and Economics, 24(7), 773-783

Smith, A.J. (1995). Estimating, Tendering, and bidding for construction: Theory and Practice, Macmillan, London.

Snyman, G.J.J. (1989a). When is a recession not a recession? A somewhat lighthearted look at the business cycle and forecasting. Juta's South African Journal of Property, 5(1), 11-17.

Snyman, G.J.J. (1989b). How the business cycle influences building costs. Juta's South African Journal of Property, 5(3), 38-44.

Snyman, G.J.J. (n. d). Using knowledge of the business cycle to forecast building costs. Building Economists, $\mathrm{P}$ O Box 7119, Stellenbosch, 7599, South Africa.

Stats Online (2011), Key Indicators, Retrieved October 17, 2011, from www.statssa.gov.za/keyindicators/keyindicators.asp

Tysoe, B.A. (1981). Construction cost and price indices: Description and use, E \& F.N., Spon, London. 